\title{
PRELIMINARY WATER SAMPLE ANALYSIS IN ENNORE OIL SPILL AREA
}

\author{
R. Nagalakshmi ${ }^{1, *}$, P. M. Rameshwaran ${ }^{2}$ and R. Santhosh ${ }^{2}$ \\ ${ }^{1}$ Civil Engineering Department, SRM Institute of Science and Technology, Katankulathur, \\ Kanchipuram-603203, TN, India \\ ${ }^{2}$ Civil Engineering Department, SRM University, Ramapuram-603201, TN, India \\ *E-mail: nagalakshmi.r@ktr.srmuniv.ac.in
}

\begin{abstract}
On $28^{\text {th }}$ January 2017 in Ennore port met an accident around Indian Standards Time 4 a.m. between two petroleum carried oil tanker ship named as M.T. BW Maple and M.T. Dawn Kanchipuram. Ennore port is one of the major port located along the Coromandel coast near to the Chennai port around $22 \mathrm{~km}$ distance. It is named as Kamaraj port limited, the first corporatized port in India and able to carryover millions of private entrepreneurs on various terminals and harbour vessel.Due to collision oil spills and spread along the shore line up to $40 \mathrm{~km}$ in the marina beech which appears dark black color high viscosity. Oil spills endanger to the marine organism, from oil, volatile gases evaporated and cause air pollution, impact to public health, impact drinking water in the nearby coastal villages, devastate air-sea interaction, natural resources and disrupt the economy. The main objective of this study is to analyze water samples in oil spill area hence oil-contaminated water sample in four different locations around Ennore port have been collected and analyzed in the laboratory. From the analysis high-temperature $28^{\circ} \mathrm{C}$ observed in the oil spill area, $\mathrm{pH}$ has acid in nature it drops below 5 and heavy metals are slightly high but in their limits only. Sea surface temperature map and oil spread details collected from INCOIS, has been estimated 20Metric Ton (MT) oil has been spilled over the Ennore port by oil spill trajectory model.

Keywords: oil spill, Ennore Port, trajectory model, sea surface temperature, metric ton, heavy metals
\end{abstract}

๑ RASĀYAN. All rights reserved

\section{INTRODUCTION}

With the rapid development of the global oceanic transportation and offshore oil exploitation industry, ocean oil spill accidents frequently occur. Oil spill monitoring has already become the primary technique for the quick and efficient handling of oil spill accidents. Marine oil spill volume is mainly controlled by three factors: the density of the oil spill; the thickness of the oil film; and the area of the oil spill ${ }^{1}$. According to Indian coast guard report, about $73 \%$ oil spill happened in ship or vessel accidents and the details of an oil spill due to accidents are shown in Fig.-1.Due to the increasing activities of marine oil resource exploitation, the oil spill has become very dangerous to the marine ecosystem, e.g., the Deepwater Horizon oil gush ${ }^{2}$. Oil spill strongly affects the marine environment and coastal zones; oil at sea is very dangerous for biological species and for human health. ${ }^{3-5}$

On $28^{\text {th }}$ January 2017 in Ennore port met an accident around Indian Standards Time 4 a.m. between two petroleum carried oil tanker ship named as M.T. BW Maple and M.T. Dawn Kanchipuram. The tank contained crude oil which has fully spill around the port and the Crude oil is a complex chemical compound such as hydrocarbons, iron, mercury, benzene, chromium, nickel, nitrogen, oxygen, sulfur, toluene, and xylene. There are four types of crude oil: in Ennore oil spill is coming under Class C: Heavy, Sticky Oils: These oils are brown or black and sticky or tarry and include most crude oils. Their toxicity is low, but if spilled, their impacts on waterfowl and wildlife can be severe. The main objective of this study to analysis water quality parameters and collect preliminary information from various sources.

\section{Study Area}

Ennore Port located on the East Coast of Tamil Nadu near to the Chennai port at the distance of $20 \mathrm{~km}$ (Fig.-2 shows the location of colloidal ships). The Port was declared as a Major Port and from June, 2001 
committed with coal supply for Tamil Nadu Electricity Board (TNEB) about 8.5 to 9 Million Tonnes per annum with the help of two coal horizontal bed with $15 \mathrm{~m}$ depth in alongside port. The Port also handles small quantities of Iron ore and POL through temporary facilities. The Port has terminals initiated and developed through private sector participation to handle liquids, coal, iron ore and containers. The Port Management is functioning with a number of faculty members ${ }^{6}$.

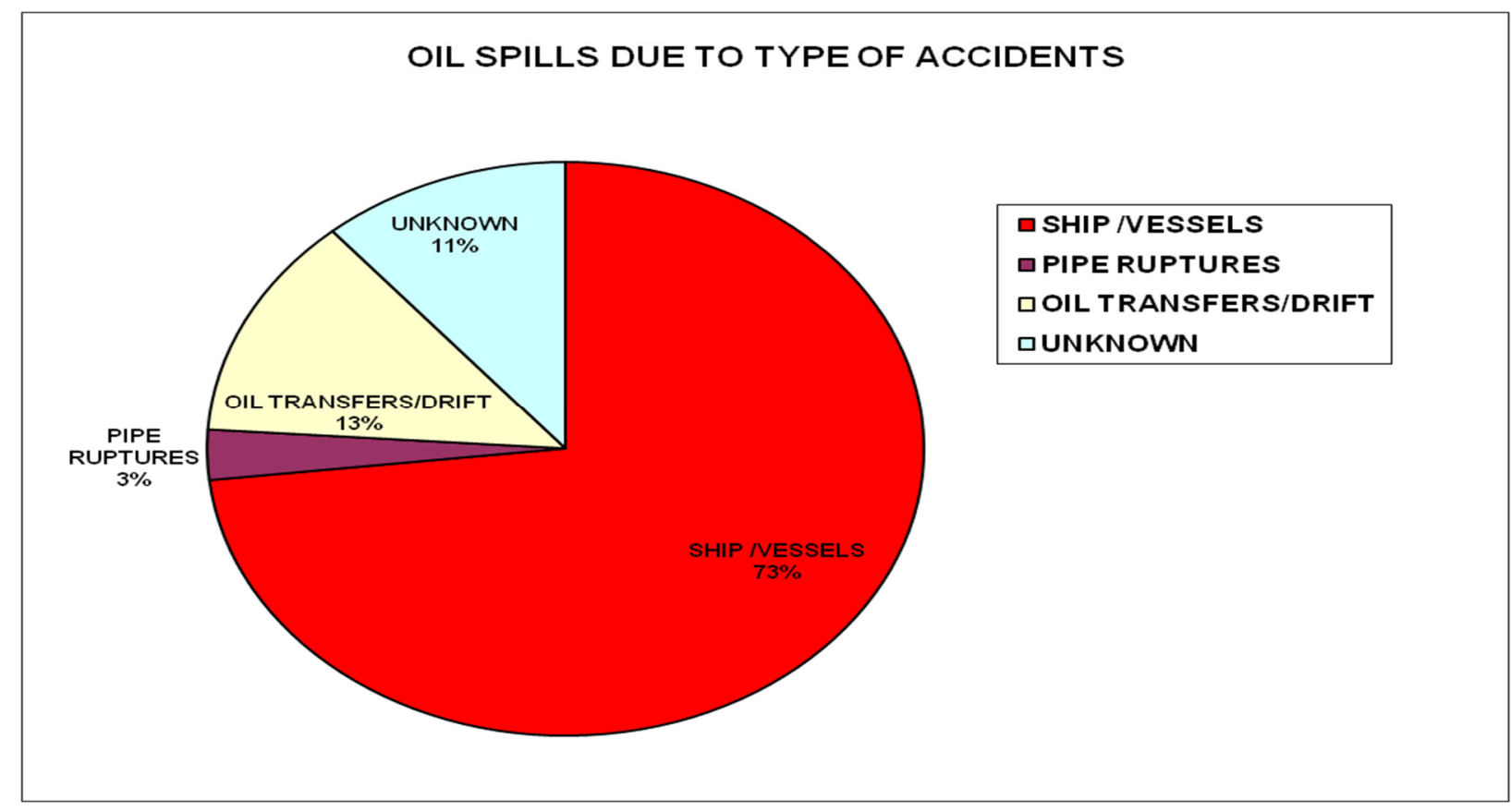

Fig.-1: The details of oil spill due to accidents(Source: Indian coast guard 2012)

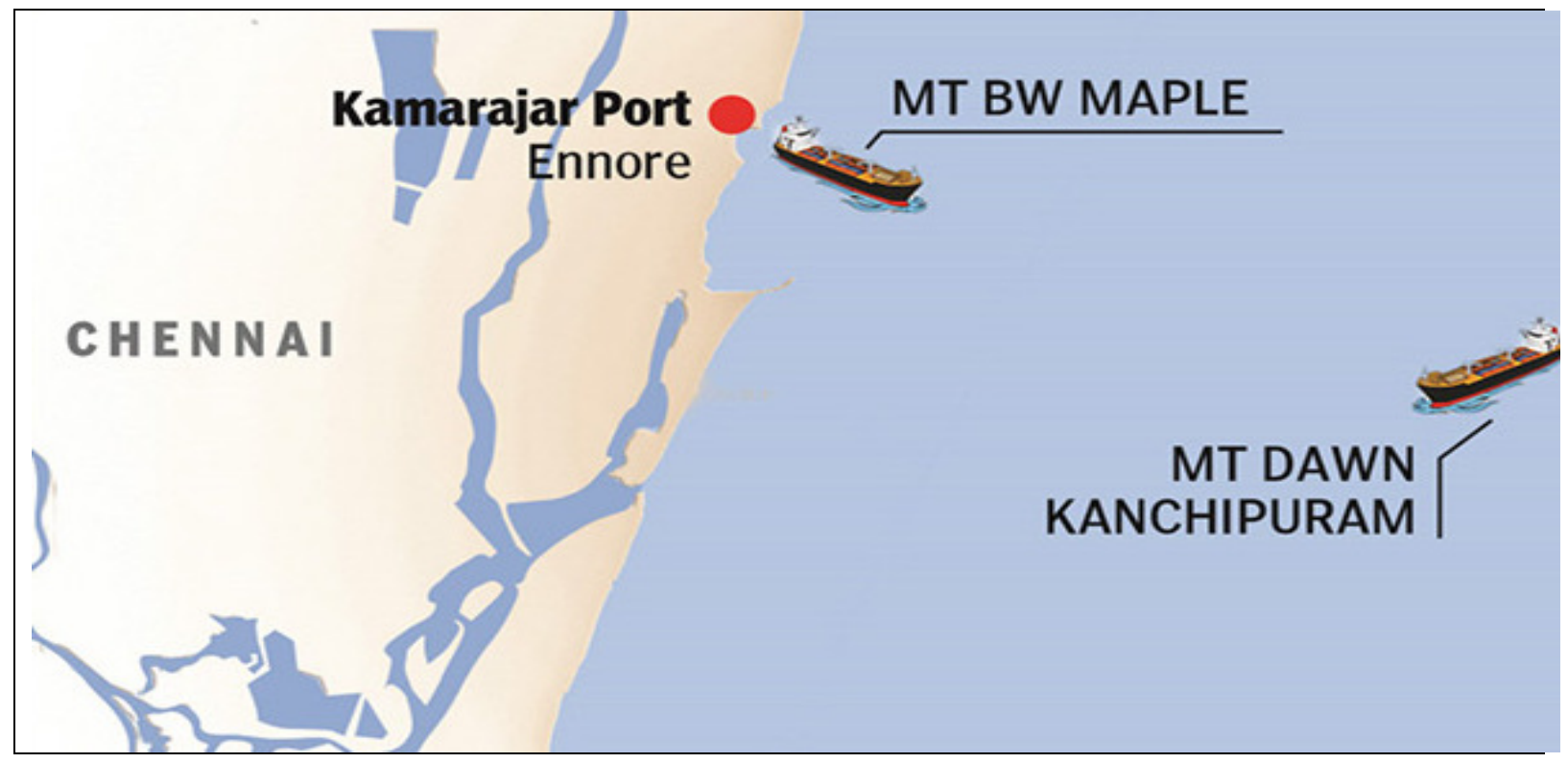

Materials and Methods

Fig.-2: The Location of Colloidal Ships (Source:Daily Thanthi)

Water samples have been collected in four different locations around oil spill region between Ennore port regions to Marina beach using standard water samplers (shallow water sampler) and transferred in 
polyethylene bottles to the SRM Environmental laboratory where physic-chemical parameters have been analyzed using standard laboratory methods of the American Public Health Association ${ }^{7}$. The samples such as temperature in air and water, $\mathrm{pH}$ have been analyzed on spot with thermometer and $\mathrm{pH}$ meter respectively. The latitude and longitude have been noted at the sampling location using Global Positioning System (GPS) ${ }^{8}$

\section{Heavy Metal Analysis}

Water samples have been collected and preserved by a standard method. According to that measured quantities of the samples have been transferred into a conical flask and $20 \mathrm{ml}$ of concentrated nitric acid (HNO3) has been added and heating gently for 20mins for the sample pre-digestion. More acid has been added and digestion was continued for 30-40mins. Digestion has stopped when a clear digest has obtained. The flask has cooled and the content transferred to a $50 \mathrm{ml}$ volumetric flask and made to the mark with distilled water. The resulting solution was analyzed for heavy metals using the Atomic Absorption Spectrophotometer (AAS) ${ }^{9}$. Oil spread details have been collected from INCOIS. Wind speed and direction and wave height and Sea Surface Temperature maps have been collected from Indian Meteorological Department (IMD).

\section{RESULTS AND DISCUSSION}

Water quality parameters are prime factors for living organisms for their survival in the marine environment have to be analyzed if any pollution has been happened and to need regular monitoring to maintain the sustainable environments ${ }^{10}$.

Physico-chemical properties of have been analyzed according to the standards of the American Public Health Association (APHA) and other standard methods. The physicochemical parameters of oil spilled water such as $\mathrm{pH}$, temperature, salinity, dissolved oxygen, TDS, oil and grease and heavy metal have been analyzed around Ennore port in four sampling location. They presented in Table -1.

\section{Temperature}

Temperature is important parameters all living resources and is a prime functioning element in photosynthesis in plants for the tropical coast and if increasing the optimum level will cause imbalance food chain. In the study area, high temperature recorded in oil spilled water comparing to ambient atmospheric temperature during the in-situ measurement. This has been checked with sea surface temperature map collected from INCOIS site map which has been shown in figure -3. High temperature with contaminated water can create eutrophication in the study area, but in this study did not notice.

\section{pH}

$\mathrm{pH}$ is the important physical parameter for an aquatic organism which denotes 0 to 14 (0-7 indicates acid nature in water, 7 is neutral and 7-14 is alkali nature). The marine organism can survival its level of alkali condition. In this study observed the $\mathrm{pH}$ level lowered below 7 which denotes an acid condition, is not favor for shell animals and start to weaken their shells because the acid reacts with calcium materials to form bicarbonate which cause the most serious effect in the fishery community to interference their reproductive cycle.. Increasing acidity in surface waters the Calcium levels in the female fish may be lowered to the point where they cannot produce eggs or larvae develop abnormally ${ }^{11}$. The $\mathrm{pH}$ level becomes around 4 - 5 to cause reduction of development and increase malformation in young fishes and embryos of fishes and many marine organisms potentially get impact due to ocean acidificaiton ${ }^{12,13}$.

\section{Salinity and Dissolve Oxygen}

Salinity is total dissolved salt in water ${ }^{14}$, in the coastal water the average salinity range is $25-35 \mathrm{ppt}$ (parts per thousand). Salinity changes contribute to change water density and to form stratification ${ }^{15}$ in the water like less dense water float on top and the more dense water at the bottom. Dissolve oxygen (DO) is oxygen dissolve in water is observed from the atmosphere and it was taken by the entire marine organism for their servile. The bottom living organism need less amount of DO (minimum 1-6 mg/L) comparing to 
shallow water fishes need more amount (minimum $4-15 \mathrm{mg} / \mathrm{L})^{16}$. Increasing the temperature cause to decrease the DO level in water which creates an insufficient amount of DO for respiration. The study area locations have been observed the salinity and dissolve oxygen slightly varied but not noticeable level.

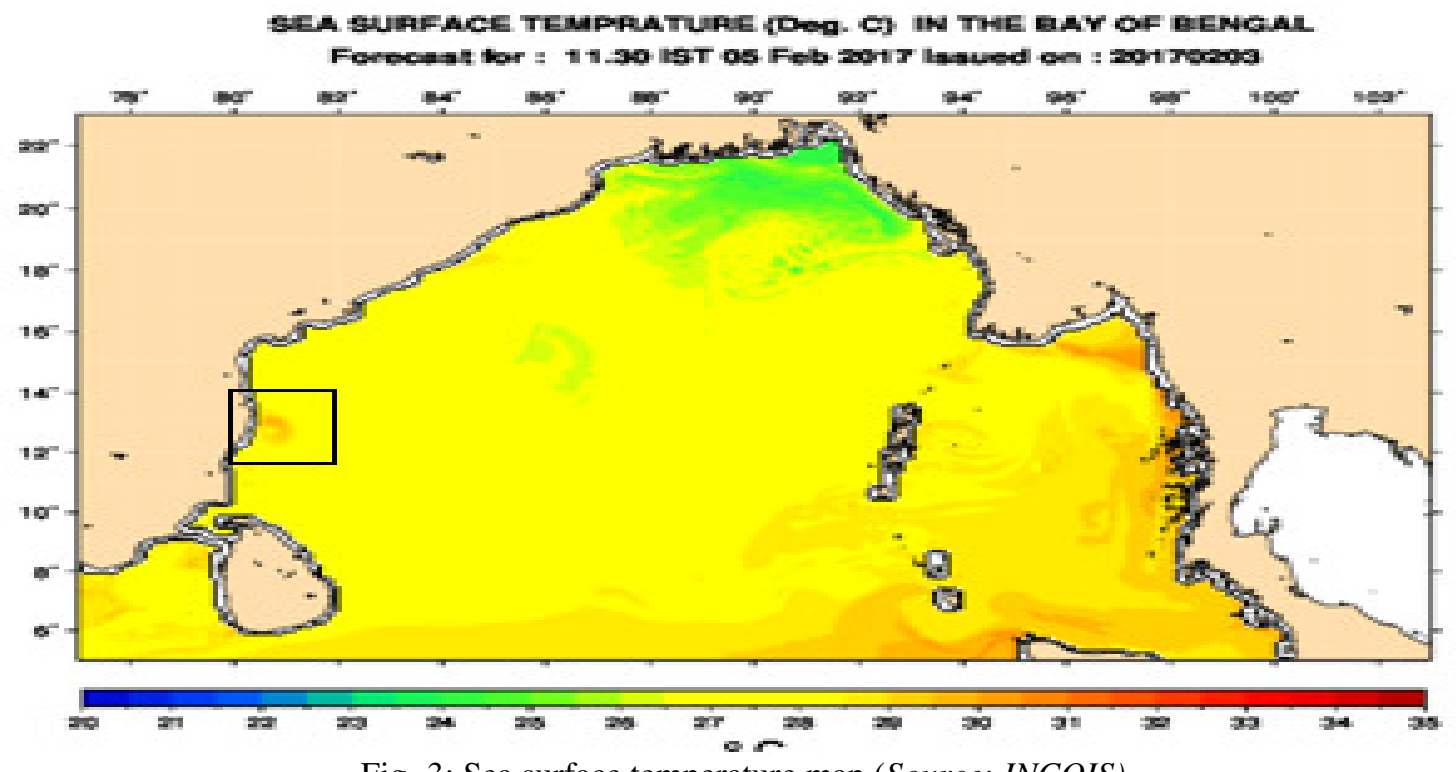

Fig.-3: Sea surface temperature map (Source: INCOIS)

Total Dissolved Solids

TDS is the dissolved ions in water the particle size is less than 2 microns ${ }^{17}$, TDS digital meter used for measurement in the study area. Salinity and TDS are correlated each other and the marine organism can adopt a particular range of salinity ${ }^{18}$. When coastal water gets contamination leads to increases the TDS level can create a toxic condition, the parameters TDS, zinc, iron, and arsenic have been within the acceptable limit in the oil spread area.

\section{Oil and Grease}

As per EPA 1986, guidance ${ }^{19}$ for Harbor water standards have $10 \mathrm{mg} / \mathrm{l}$ oil and grease has an allowable limit but in this oil spill shows above $1000 \mathrm{mg} / \mathrm{l}$ around Ennore port. Fully spread over the water and cause several damages or lethal effect to the aquatic life mainly for sea turtles and sea birds, in this study has not conducted the impact of living resources.

Oil spill spreads analysis carried by INCOIS using its oil spill trajectory model by using wind speed, direction, and wave action to predict the oil drift. In this model has been run from 28.01.2017, 04.00hrs to 08.02.2017, $23.00 \mathrm{hrs}$ and oil cleaning operation by the government has not been taken into account in this modeling. The change in the quantity of the oil due to clean up operations is not considered in modeling the drift. 20MT oil has been a spill in Ennore port and spread over along the coromandal coast in the east direction up to marina beech. The oil spill spread stretch shown in Fig.-3.

\section{CONCLUSION}

In this study conducted the water sample analysis as a preliminary survey of oil spill spread. From this analysis, the oil spill area has high temperature comparing to normal which lead to change the food chain and lethal effect to the living organism. Next parameter is $\mathrm{pH}$ reduce in the study area which causes most serious impact on the shell fishes and fish community for their life cycle due to acidity and the other parameters slightly varied is not noticeable level. The cleanup process is very slow which cause deep damage to the environment and aquatic life. Numbers of fishes and sea turtles have been dead due to oil slick which has under investigation stage. The study area needs deep investigation for further environmental impact. 
RASĀYAN J. Chem.

Vol. 11 | No. 1 |181-186 | January - March | 2018

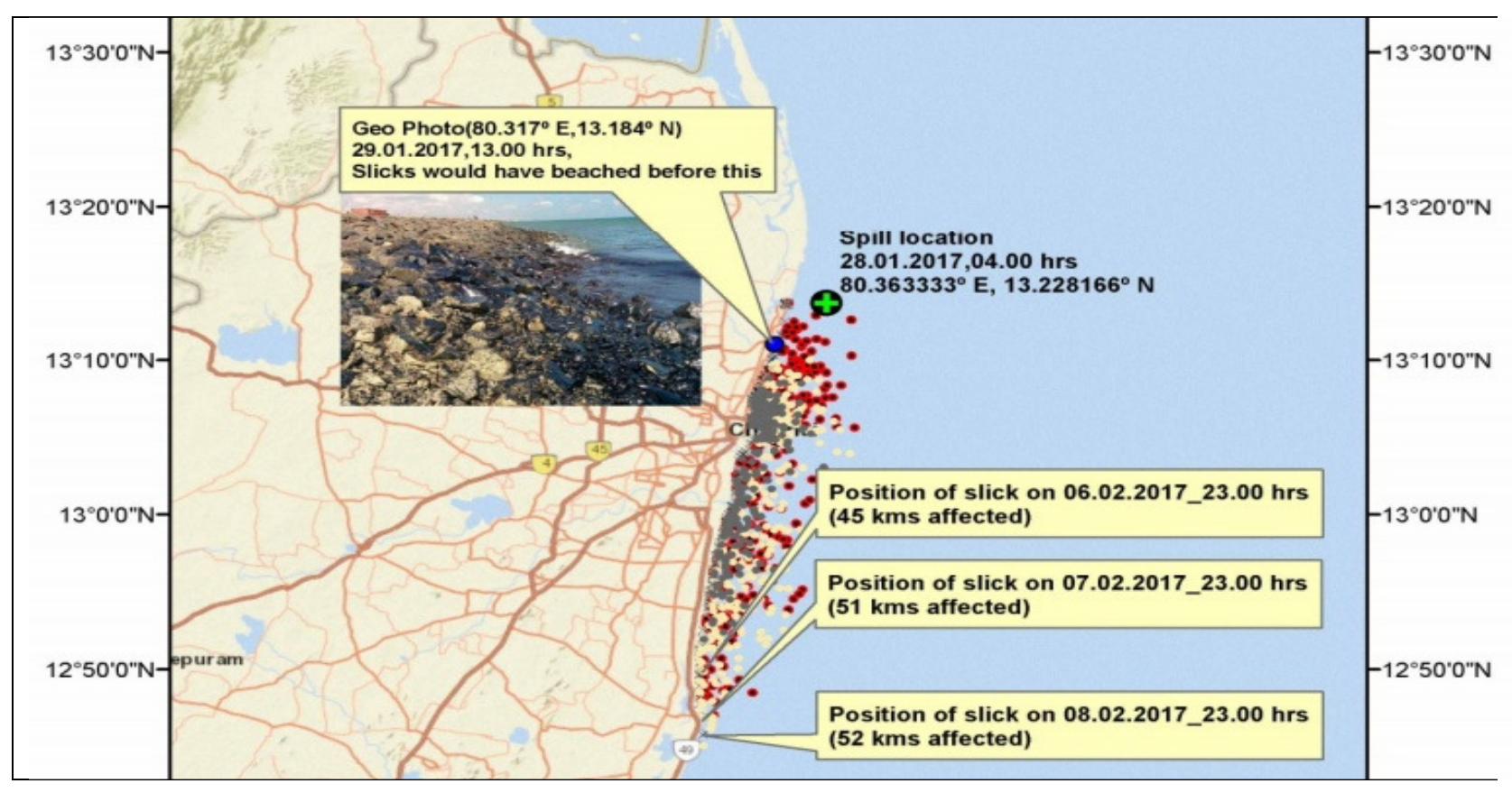

Fig.-3: The Oil Spill Spread Stretch (Source: INCOIS)

Table-1: Physico-chemical Characteristics of Water Sample

\begin{tabular}{|c|c|c|c|c|}
\hline $\begin{array}{c}\text { Parameter and } \\
\text { Location }\end{array}$ & $\begin{array}{l}\text { Sampling No } 1 \\
\text { Latitude: } \\
13^{\circ} 20^{\prime} 10^{\prime \prime} \mathrm{N} \\
\text { Longitude: } \\
80^{\circ} 10^{\prime} 40^{\prime \prime} \mathrm{E}\end{array}$ & $\begin{array}{l}\text { Sampling No } 1 \\
\text { Latitude: } \\
12^{\circ} 25^{\prime} 30^{\prime \prime} \mathrm{N} \\
\text { Longitude: } \\
80^{\circ} 11^{\prime} 30^{\prime \prime} \mathrm{E}\end{array}$ & $\begin{array}{l}\text { Sampling No } 3 \\
\text { Latitude: } \\
12^{\circ} 40^{\prime} 20^{\prime \prime} \mathrm{N} \\
\text { Longitude: } \\
80^{\circ} 14^{\prime} 42^{\prime \prime} \mathrm{E}\end{array}$ & $\begin{array}{c}\text { Sampling } 4 \\
\text { Latitude: } \\
12^{\circ} 45^{\prime} 50^{\prime \prime} \mathrm{N} \\
\text { Longitude: } 80^{\circ} 25^{\prime} 10 \\
\text { "E }\end{array}$ \\
\hline Temperature $\left({ }^{0} \mathrm{C}\right)$ in Air & 25.2 & 25.1 & 25.2 & 25.2 \\
\hline Temperature $\left({ }^{0} \mathrm{C}\right)$ in Water & 30.6 & 30.6 & 29.3 & 29.0 \\
\hline $\mathrm{pH}$ & 5.3 & 5.2 & 6.3 & 6.8 \\
\hline Salinity (ppt) & 35.2 & 35.2 & 35.6 & 35.6 \\
\hline Dissolve Oxygen (mg/l) & 4.2 & 4.1 & 3.6 & 3.5 \\
\hline TDS $(\mathrm{mg} / \mathrm{l})$ & 1620 & 1510 & 1550 & 1510 \\
\hline Oil and Grease $(\mathrm{mg} / \mathrm{l})$ & 1363 & 1333 & 1121 & 1123 \\
\hline Zinc $(\mathrm{mg} / \mathrm{l})$ & 0.299 & 0.223 & 0.221 & 0.2262 \\
\hline Iron $(\mathrm{mg} / \mathrm{l})$ & 0.674 & 0.524 & 0.545 & 0.564 \\
\hline Arsenic (mg/l) & 0.021 & 0.016 & 0.011 & 0.017 \\
\hline
\end{tabular}

\section{REFERENCES}

1. Song Dongmei, Liu Bin, Chen Shouchang, Ma Yi, Zhang Yajie, Shen Chen and Cui Jianyong, Aquatic Procedia, 3, 133(2015).

2. V. Klemas, Journal of Coastal Research, 26, 789(2010).

3. M.D. Garza-Gil, A. Prada-Blanco, M.X. Vazquez-Rodriguez, Ecol. Econ., 58, 842(2006).

4. A. McCrea-Strub, K. Kleisner, U. R. Sumaila, W. Swartz, R. Watson, D. Zelle, D. Pauly, Journal of Fisheries, 36, 332(2011).

5. ITOPF. Handbook. Retrieved from http://www.itopf.com/knowledge-resources/documents-guides (2012). 
RASĀYAN J. Chem.

Vol. 11 | No. 1 |181-186 | January - March | 2018

6. Ennore Port Business Plan Consultancy HPC-CES Final Report, p.15 (2007).

7. APHA/AWWA/WEF, American Public Health Association, Washington, DC (1995).

8. B. C. Sundara Raja Reddy, N. Jayaraju, K.R.Reddy, Marine Science , 2, 66(2012).

9. Joel, F. Ogbonna, Amajuoyi, A. Chinomso, J. Appl. Sci. Environ. Manage., 13(3) 99(2009).

10. R. Nagalakshmi , K. Prasanna and S. Prakash Chandar, Rasayan Journal of Chemistry, 9(4), 634 (2016)

11. EPA's Hazardous Waste Regulations, 19, (1980).

12. J. Raven, K. Caldeira, H. Elderfield, O. Hoegh-Guldber, P. Liss, U. Riebesell, J. Shepherd, C. Turley, A. Watson, Policy Document12/05, Royal Society, London (2005).

13. V.J. Fabry, B.A. Seibel, R.A.Feely, J. C. Orr, J.Mar.Sci., 65, 414(2008).

14. Salinity def, R.G. Wetzel, Limnology, San Diego, CA, Academic Press (2001).

15. SWRCB. Electrical Conductivity/Salinity Fact Sheet. In The Clean Water Team Guidance from http://www.swrcb.ca.gov/water_issues/programs/swamp/docs/cwt/guidance/3130en.pdf (2002).

16. Plant Growth Factors: Photosynthesis, Respiration, and Transpiration. From http://www.ext.colostate.edu/mg/gardennotes/141.html (2013)

17. EPA. 5.8 from http://water.epa.gov/type/rsl/monitoring/vms58.cfm (2012).

18. Virginia
http://web.vims.edu/bio/shallowwater/physical_characteristics/salinity.html (2005).

19. EPA, 1986 GSR 7, dated Dec. 22, (1998).

[RJC-1774/2017] 